\title{
Domestication and Responses of Wheat (Triticum aestivum L) Growth, Yield Parameters, Quality Indices and Soil Fertility improvement to Different Organic Fertilizers
}

\author{
Emmanuel Ibukun Oluwa Moyin Jesu* \\ Agronomy Department, Federal College of Agriculture, Nigeria
}

Received: 眥 April 17, 2018; Published: 㘹 April 30, 2018

*Corresponding author: Emmanuel Ibukun Oluwa Moyin Jesu, Agronomy Department, Federal College of Agriculture, Nigeria

\begin{abstract}
Purpose: Field and nursery experiments were conducted in Akure in the rainforest zone of Nigeria to evaluate the effects of woodash, pig, goat and poultry manures on the soil fertility improvement, growth, grain yields parameters, crude fibre, crude ash, protein and nitrogen of wheat (Triticum aestivum L) in 2014 and 2015 cropping seasons.
\end{abstract}

Methods. The four (4) organic fertilizer treatments were applied each at 6t/ha with a reference treatment NPK 15-15-15 fertilizer applied at $300 \mathrm{~kg} / \mathrm{ha}$ and a control treatment which were replicated four times and arranged in a randomized complete block design.

Results: The results showed significant increases $(\mathrm{P}<0.05)$ in the soil nutrients, growth and grain yield, crude fibre, protein, nitrogen, crude ash, straw yield and root biomass of wheat under different organic fertilizers application compared to the control treatment. The highest values of wheat plant height, leaf area, number of tillers, stem girth, number of spikelets/plant, leaf population, straw weight, root biomass, grain yields, crude fibre, crude ash, nitrogen and protein were obtained with the application of poultry manure followed by NPK 15-15-15 fertilizer, pig, goat manures and wood ash respectively. Wheat grains yield, straw weight, root biomass, crude fibre, $\%$ nitrogen, crude fibre and crude ash, plant height leaf area, number of tillers, stem girth, number of spikelets/plant and leaf population increased by $13 \%, 2 \%, 1 \%, 27 \%, 33 \%, 33 \%, 27 \%, 14 \%, 10 \%, 2 \%, 11 \%$ and $15 \%$ respectively with the application of poultry manure compared to NPK 15-15-15 fertilizer. Wood ash application produced the highest values of soil $\mathrm{pH}, \mathrm{K}, \mathrm{Ca}$ and $\mathrm{Mg}$ while the application of poultry manure treatment gave the highest values of Soil O.M, N and moderate values of P, K, Ca and Mg. NPK 15-15-15 fertilizer application decreased soil O.M, Ca, Mg and had the highest K/Mg, K/Ca and P/Mg ratios of 85:1, 127:1 and 1280:1 compared to 3:1 K/Ca, K/Mg 4:1 and P/Mg 57:1 in poultry treatment.

Conclusion: Poultry manure applied at $6 \mathrm{t} / \mathrm{ha}$ gave the best results in improving soil properties, growth, grain yield crude ash, crude fibre, nitrogen and crude protein of wheat and this was because of its balanced nutrient contents and the least $\mathrm{C} / \mathrm{N}$ ratio which enhanced faster decomposition and uptake of nutrients.

Keywords: Domestication; Growth; Yield of wheat; Soil fertility improvement; Proximate analysis and organic fertilizers

\section{Introduction}

Wheat (Triticum aestivum $L$ ) belongs to the family Poaceae (Gramineae) and originated from Ethopian Highlands [1]. Wheat is one of major crop in the temperate countries used for human

food and livestock and can be grown in different agro-climatic zones Iftikhar [2] and Hussan [3]. Shewry [4] reported that wheat whole grains contributed essential amino acids, minerals, vitamins, 
beneficial phytochemicals and dietary fibre components to the human diet. Besides, wheat grain is a staple food used to make flour for leavened, flat, and steamed breads, biscuits, cookies, cake, breakfast cereal, pasta, noodles, fermented alcoholic beverages (beer) and biofuel Sharma [5]. They reported further that the gluten protein fraction in wheat confers the visco-elastic properties that allowed the dough to be processed into above mentioned food products. Shewry [6] also explained that high content of starch (60$70 \%$ ) in wheat whole grain and relatively low protein content (8$15 \%$ ) made the crop still important source of calories and protein for human and livestock nutrition. Therefore, the nutritional importance of wheat proteins should not be under estimated particularly in less developed countries where bread, noodles, burger and other products provide a substantial proportion of the diet. Despite the economic and nutritional importance of wheat cultivation in Nigeria and other African countries, its production output has not met the current high demand by the people because of low yield. The wide gap in the supply and demand for wheat in Nigeria has put serious pressure on the country foreign exchange reserve. Central Bank of Nigeria CBN [7] reported that Nigeria spent N1.30 trillion naira annually to import wheat for domestic and industrial uses which cannot be sustained because of dwindling oil prices.

The trend of low wheat yield could be attributed to factors such as lack of improved agronomic practices for its cultivation by farmers, vagaries of weather conditions and climate change, shortage of sufficient water and mineral nutrients, effects of pests and diseases and increased population pressure on land which allowed continuous cultivation without fertilizer use. Therefore, different efforts meant to increase soil nutrients (i.e soil fertility improvement) are limited by high cost of inorganic fertilizers and the effect of the continuous use of such fertilizers on the destruction of soil properties Moyin [8]. Current and future concerns for researchers, agronomists, food policy makers and processors are to look for ways of sustaining increased wheat production and quality with reduced inputs of agro-chemicals, inorganic fertilizers and encouraged massively the use of low cost organic fertilizers for both human and livestock nutrition. This justifies the need for the use of poultry, pig, goat manures and woo dash as source of fertilizers for soil fertility improvement in this research study. In-addition, wheat has not been widely domesticated in Nigeria, West African countries and other regions in the world with similar climatic conditions. The few farmers growing wheat in the Northern regions of Nigeria where rainfall is very low $(600 \mathrm{~mm} /$ annum) depended heavily on irrigation which is very expensive,

Table 1: The Climatic data for Akure in 2014 and 2015. technical and increased the cost of production. However, there have been no traces of wheat cultivation in the South West Nigeria, where rainfall is bi-modal between $1000-2064 \mathrm{~mm}$ per annum and annual temperature between 29 -32oC. Feldman [9] reported that provision of sufficient water, mineral nutrients and effective control of pests and diseases were important for high yields of wheat.

Now that there is an increasing climate change effects in Nigeria and throughout the world, thus neccesitating an urgent need to encourage farmers in Southern region of Nigeria, West African countries and other regions in the world with similar climatic conditions to domesticate wheat cultivation on commercial basis under rainfed agriculture especially the second peak of raining season between July and November using low cost organic fertilizer inputs. Having reviewed literature critically, there is a paucity of research information on the use poultry, pig, goat manures and wood ash on the growth and yield parameters of wheat except the works of Jubrin [10] on the effect of poultry manure on herbage production of wheat, Abdul [11] using NPK fertilizers on growth and yield of wheat and Jabbar [12] who worked on effect of potassium application on yield and protein contents of late sown wheat. The choice of wood ash, pig, poultry and goat manures as sources of organic fertilizer materials in the research study was due to their availability and abundance in large quantities from the study area and the surrounding communities where majority of the farmers are cassava growers with associated processing mills, poultry, pig and goat producers.

\section{Purpose of the experiment}

The following research questions would be answered for the experiment (a) Is there any significant difference between the applied organic fertilizers on growth and yield parameters of wheat? (b) Is there any significant difference between the applied organic fertilizers and post cropping soil properties?

The objectives of the research work are to (a) determine the effect of poultry; pig, goat manures and wood ash on the growth, yield and quality parameters of wheat (b) determine the effect of these organic fertilizers on post cropping soil properties.

\section{Materials and Method}

The nursery and field experiments were carried out in Akure, South West in the rainforest zone of Nigeria (elevation $10 \mathrm{~m} 7^{\circ} 15^{1} \mathrm{~N}$, $5^{\circ} 15^{1} \mathrm{E}$ ) in 2014 and was repeated in 2015 to validate the results. The climatic data for 2014 and 2015 is presented in Table 1 while the soil is loamy sand, skeletal, kaolinitic, isohyperthomic oxic paleustalf (Alfisol) Soil Survey Staff [13].

\begin{tabular}{|c|c|c|c|c|c|c|c|c|c|c|}
\hline Months & \multicolumn{2}{|c|}{ Rainfall (mm) } & \multicolumn{2}{c|}{ Temperature OoC } & \multicolumn{2}{c|}{$\begin{array}{c}\text { Solar energy density MJ/ } \\
\mathbf{m} \text { /day }\end{array}$} & \multicolumn{2}{|c|}{$\begin{array}{c}\text { Average Sunlight Hours/ } \\
\text { day }\end{array}$} & $\begin{array}{c}\text { Average day light hours/ } \\
\text { day }\end{array}$ \\
\hline & $\mathbf{2 0 1 4}$ & $\mathbf{2 0 1 5}$ & $\mathbf{2 0 1 4}$ & $\mathbf{2 0 1 5}$ & $\mathbf{2 0 1 4}$ & $\mathbf{2 0 1 5}$ & $\mathbf{2 0 1 4}$ & $\mathbf{2 0 1 5}$ & $\mathbf{2 0 1 4}$ & $\mathbf{2 0 1 5}$ \\
\hline January & 40.50 & 36.48 & 31.40 & 31.40 & 19.27 & 18.90 & 6.5 & 6.8 & 11.46 & 11.50 \\
\hline
\end{tabular}




\begin{tabular}{|c|c|c|c|c|c|c|c|c|c|c|}
\hline February & 51.89 & 36.28 & 31.60 & 30.90 & 21.60 & 22.00 & 7.60 & 7.90 & 11.55 & 22.30 \\
\hline March & 130.32 & 128.53 & 31.40 & 31.30 & 20.40 & 20.80 & 5.85 & 6.00 & 12.10 & 12.25 \\
\hline April & 177.19 & 192.82 & 31.60 & 31.90 & 19.10 & 19.80 & 5.50 & 5.70 & 12.15 & 12.40 \\
\hline May & 227.45 & 210.49 & 31.20 & 31.10 & 19.40 & 20.30 & 6.25 & 6.20 & 12.50 & 12.25 \\
\hline June & 226.35 & 241.53 & 32.0 & 30.0 & 18.30 & 17.40 & 5.40 & 5.70 & 12.29 & 12.31 \\
\hline July & 320.40 & 280.10 & 28.60 & 29.80 & 15.60 & 14.40 & 2.95 & 3.82 & 12.28 & 12.35 \\
\hline August & 321.15 & 118.50 & 28.60 & 28.90 & 12.21 & 13.30 & 3.75 & 3.00 & 12.20 & 12.26 \\
\hline September & 297.42 & 332.82 & 29.40 & 31.10 & 16.83 & 16.50 & 3.45 & 3.50 & 12.19 & 12.18 \\
\hline October & 206.37 & 221.82 & 29.30 & 30.50 & 18.86 & 19.0 & 5.30 & 5.10 & 12.0 & 11.58 \\
\hline November & 217.01 & 165.10 & 30.80 & 30.90 & 23.50 & 23.0 & 7.95 & 7.40 & 11.56 & 11.47 \\
\hline December & 13.36 & 16.16 & 28.70 & 31.60 & 20.80 & 20.40 & 5.15 & 4.90 & 11.44 & 11.30 \\
\hline
\end{tabular}

Source: Agro-climatology Department Ondo State Ministry of Agriculture

\section{Pre cropping Soil Sampling and analysis}

30 core samples were collected from $0-15 \mathrm{~cm}$ depth, bulked, air-dried, sieved with $2 \mathrm{~mm}$ sieve for routine analysis. Soil P was extracted by Bray P1 extractant and the extract was developed on Murphy blue coloration and determined on a spectronic 20 [14]. The soil pH (1:1 soil/water and 1:2 soils/0.01M $\mathrm{CaCl}_{2}$ ) was read on pH meter Crockford [15]. The organic matter was determined using wet oxidation method through chromic acid digestion Walkley [16]. Soil. $\mathrm{K}, \mathrm{Ca}, \mathrm{Mg}$ and Na were extracted with $1 \mathrm{M} \mathrm{NH}_{4} \mathrm{OAC} \mathrm{pH} 7$ and their contents K, Ca and Na were read on the flame photometer [17] while Mg content was read and determined on atomic absorption spectrophotometer. The Soil $\mathrm{N}$ was determined using the micro Kjedahl method. Jackson [18] while the micronutrients ( $\mathrm{Fe}, \mathrm{Cu}$, $\mathrm{Zn}$ and $\mathrm{Mn}$ ) were extracted with $0.01 \mathrm{M} \mathrm{HCl}$ and read on atomic absorption spectrophotometer. Parricle size analysis was carried out using hydrometer method Bouycous [19].

The soil pH 5.63 showed that the soil is slightly acidic. The soil organic matter $0.34 \%$ and soil available $P 5.22 \mathrm{mg} / \mathrm{kg}$ were far below 3\% 0.M and 10mg/kg P critical levels recommended for sustainable crop production in South West Nigeria Agboola [20]. The soil exchangeable bases ( $\mathrm{K}, \mathrm{Ca}, \mathrm{Mg}$ and $\mathrm{Na}$ ) were below $0.20 \mathrm{mmol} /$ $\mathrm{kg}$ recommended critical level in the study area Folorunso [21]. The soil textural class is loamy sand while the micronutrients were sufficient for crop production; higher than $5.0 \mathrm{mg} / \mathrm{kg} \mathrm{Fe}, 3.0 \mathrm{mg} /$ $\mathrm{kg} \mathrm{Zn}, 1.0 \mathrm{mg} / \mathrm{kg} \mathrm{Cu}$ and $\mathrm{Mn} 1.5 \mathrm{mg} / \mathrm{kg}$ critical levels respectively Adeoye [22]. The soil N content of $0.05 \%$ was lower than $0.15 \% \mathrm{~N}$ critical level recommended for crops by Sobulo [23] (Table 2 ).

Table 2: Pre-cropping soil analysis for wheat.

\begin{tabular}{|c|c|}
\hline Soil Properties & Values \\
\hline Soil $\mathrm{pH}(1: 1$ Soil/water $)$ & 5.63 \\
\hline Soil $\mathrm{pH}(1: 2$ Soil/0.01M) & 4.69 \\
\hline Organic matter $(\%)$ & 0.34 \\
\hline Available P $(\mathrm{mg} / \mathrm{kg})$ & 5.22 \\
\hline \% Soil N & 0.05 \\
\hline Exchangeable bases & \\
\hline
\end{tabular}

\begin{tabular}{|c|c|}
\hline $\mathrm{K}+(\mathrm{mmol} / \mathrm{kg})$ & 0.06 \\
\hline $\mathrm{Ca}^{2}+(\mathrm{mmo} 1 \mathrm{~kg})$ & 0.08 \\
\hline $\mathrm{Mg}^{2}+(\mathrm{mmo} 1 / \mathrm{kg})$ & 0.03 \\
\hline $\mathrm{Na}+(\mathrm{mmo} 1 / \mathrm{kg})$ & 0.10 \\
\hline $\mathrm{Micronutrients}$ & \\
\hline $\mathrm{Fe}^{2}+(\mathrm{mg} / \mathrm{kg})$ & 7.40 \\
\hline $\mathrm{Zn}^{2}+(\mathrm{mg} / \mathrm{kg})$ & 3.47 \\
\hline $\mathrm{Mn}^{2}+(\mathrm{mg} / \mathrm{kg})$ & 1.61 \\
\hline $\mathrm{Cu}^{2}+(\mathrm{mg} / \mathrm{kg})$ & 2.37 \\
\hline $\mathrm{Textural} \mathrm{Analysis}$ & \\
\hline Sand $(\%)$ & 75.20 \\
\hline Silt $(\%)$ & 15.50 \\
\hline Clay $(\%)$ & 9.30 \\
\hline Texture Class & Loamy sand \\
\hline Exchangeable Acidity & \\
\hline H+ ions & 3.85 \\
\hline A13 ions & 0.08 \\
\hline
\end{tabular}

\section{Sources and processing of organic fertilizers used for} the experiment

Poultry, pig and goat manures were obtained from the 10,000 poultry birds, 500 pigs and 500goats in the livestock unit of Federal College of Agriculture, Akure while the wood ash was obtained from the large scale cassava processing unit which processed cassava tubers from 10,000 hectares of cassava farm in the same institution. NPK 15-15-15 fertilizer was purchased from Agricultural Development Programme (ADP), Akure Ondo State while the imported wheat seeds (Durum L) were also purchased from a certified seed company, Agro-Farm enterprises, Akure Nigeria. The organic fertilizer materials were processed; wood ash was sieved with $2 \mathrm{~mm}$ sieve to remove pebbles and charcoals while poultry, pig and goat manures were cured before application.

\section{Chemical analysis of the organic fertilizers used}

Two (2) grammes each of the processed organic fertilizers were analysed. $\mathrm{P}, \mathrm{K}, \mathrm{Ca}$ and $\mathrm{Mg}$ analysis was done using wet 
digestion method based on $25-5-5 \mathrm{ml}$ of $\mathrm{HNO}_{3}-\mathrm{H}_{2} \mathrm{SO}_{4}-\mathrm{HCLO}_{4}$ acids while Nitrogen $(\mathrm{N})$ content was determined by the kjedahl method Jackson [18]. Table 3 presents the chemical analysis of the organic fertilizers used for the research experiment. Poultry manure had the highest values of $\mathrm{N}, \mathrm{P}$ and least value of $\mathrm{C} / \mathrm{N}$ ratio followed by pig, goat manures and wood ash respectively. The wood ash had Table 3a. the highest values of $\% \mathrm{~K}, \mathrm{Ca}, \mathrm{Mg}, \mathrm{Fe} \mathrm{Mn}, \mathrm{Cu}$ and $\mathrm{Zn}$ respectively. Its highest $\mathrm{C} / \mathrm{N}$ value of 11.76 might delay decomposition and quick release of nutrients to crops when compared to poultry, pig and goat manures respectively. The NPK 15-15-15 fertilizer had 15\%N, $15 \% \mathrm{P}$ and $15 \% \mathrm{~K}$ nutrient contents respectively.

\begin{tabular}{|c|c|c|c|c|c|c|c|}
\hline Fertilizer Treatments & N (\%) & C (\%) & C/N ratio & P mg/kg & K (\%) & Ca (\%) & Mg (\%) \\
\hline Poultry Manure & 4.32 & 30.00 & 6.93 & 385.00 & 9.70 & 3.30 & 4.10 \\
\hline Pig Manure & 3.72 & 27.00 & 7.25 & 312.00 & 14.45 & 3.10 & 4.80 \\
\hline Goat Manure & 2.52 & 20.00 & 7.93 & 167.50 & 9.97 & 2.90 & 4.50 \\
\hline Wood ash & 1.53 & 18.00 & 11.76 & 86.00 & 23.02 & 9.40 & 8.52 \\
\hline
\end{tabular}

Table 3b: Chemical analysis of the organic fertilizers.

\begin{tabular}{|c|c|c|c|c|}
\hline Treatments & Fe(\%) & Mn2+(\%) & $\mathbf{C u 2 + ( \% )}$ & $\mathbf{Z n} \%$ \\
\hline Poultry Manure & 37.85 & 1.66 & 0.15 & 1.26 \\
\hline Pig Manure & 34.00 & 1.62 & 0.17 & 1.34 \\
\hline Goat Manure & 34.50 & 1.60 & 0.16 & 1.30 \\
\hline Wood ash & 65.51 & 11.92 & 0.66 & 1.83 \\
\hline
\end{tabular}

\section{Nursery establishment for wheat seedlings}

Land clearing with packing of debris where carried out followed by construction of bamboo made of erected bamboo poles and covered on the top with moderate spread of palm fronds. Ten nursery beds with a size of $4 \mathrm{mx} 4 \mathrm{~m}$ each were prepared. The wheat seeds (durum L) variety were sown in June manually into rows spaced at $20 \mathrm{~cm}$ apart, covered lightly with soil, watered regularly twice a day (morning and evening time) to aid good seeds germination and establishment of seedlings. Germination of wheat seeds occurred four days after planting and seedlings were nursed for 3 weeks before transplanting. The nursery experiment is important because direct sowing of wheat seeds on field will not bring out healthy seedlings with high germination percentage, thus, the use of shade structure was to control the prevailing temperature for higher rate of seeds germination to plant on large scale field.

\section{Field Experiment}

The experimental land was cleared, ploughed, harrowed and

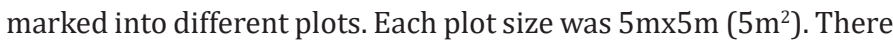
were four organic fertilizer treatments, namely wood ash, poultry, pig and goat manures, applied at $6 \mathrm{t} / \mathrm{ha}$ with a reference treatment NPK 15-15-15 fertilizer applied at $3000 \mathrm{~kg} / \mathrm{ha}$ and a control treatment (no fertilizer application). The experiment was arranged in a randomized complete block design and replicated four times. The choice of 6t/ha for wood ash, pig, goat and poultry manure for this research was based on the research works of Folorunso [24] and Moyin Jesu [25] on determination of soil critical levels for N,P,K, $\mathrm{Ca}$ and Mg using organic fertilizer materials and concluded that application of $6 \mathrm{t} / \mathrm{ha}$ was the best critical level for optimum crop yield in the study area.
The incorporation of the organic fertilizers into the soil was done one week before transplanting the wheat seedlings using hand trowel. Twenty one day old wheat seedlings were transplanted to the experimental plots at $20 \mathrm{~cm}$ spacing between rows and $5 \mathrm{~cm}$ within rows on July, 2014. After transplanting, watering was carried out every morning and evening for one week for full establishment of seedlings. Tillering of wheat seedlings started at 4 weeks after transplanting. Weeding operation was done manually 14 days after transplanting and continued at three (3) weeks interval until harvest. Wheat seedlings were sprayed with Avesthrin (Cypermethrin 10EC) at $10 \mathrm{ml} /$ litre of water at 3 weeks interval until 9 weeks after transplanting to control leaf defoliating insects and other pests of wheat.

Wheat growth parameters such as plant height $(\mathrm{cm})$, number of tillers, number of spikelets, leaf population, stem girth $(\mathrm{cm})$ leaf area (cm2) and plant population were measured starting from 15 days after transplanting (DAT) until 70 days after transplanting. The leaf area was estimated using the non-destructive and accurate method of Pandey and Singh (2011) based on determination of individual leaf area using a simple equation leaf area $\left(\mathrm{cm}^{2}\right)=\mathrm{x} / \mathrm{y}$ where $\mathrm{x}$ is the weight ( $\mathrm{g}$ ) of the area covered by leaf outline on a millimeter graph paper and $y$ is the weight of one $\mathrm{cm}^{2}$ of the same graph paper. The formation of panicles in wheat started between 7-8 weeks after planting. At 12 weeks after planting, harvesting of matured wheat panicles at $15 \%$ moisture started for each treatment as they attain maturity, the panicles were cut from the base using knives, weighed $(\mathrm{kg})$, bagged and sun dried for five days to attain $13 \%$ moisture content. The dried panicles were threshed to remove carefully the wheat grain yield and weighed per each treatment plot. The weight of wheat straw and root biomass were also measured to determine the ratio between the grain yields and shoot weight.

\section{Proximate analysis of wheat grains}

2 grammes each of wheat grains per treatment were weighed into crucibles and placed in a muffled furnace for 6 hours at $450 \mathrm{oC}$. Thereafter, ash was allowed to cool down, made into solution and filtered to obtain clear solution through which the crude fibre, 
nitrogen, crude protein $(\% \mathrm{~N} \times 6.25)$ and crude ash were determined as described by AOAC [26].

\section{Post cropping soil analysis}

Soil samples were collected after harvesting from each of the treatment plot, bulk together, air-dried, sieved and analysed for soil $\mathrm{N}, \mathrm{P}, \mathrm{K}, \mathrm{Ca}, \mathrm{Mg}, \mathrm{pH}$ and O.M as earlier described for pre-cropping soil analysis.

\section{Statistical Analysis}

All data collected on the growth and yield parameters of wheat were subjected to Analysis of Variance (ANOVA) F-test and their means were separated using Duncan Multiple Range Test at 5\% level of significance Gomez [27].

\section{Results}

The growth parameters of wheat plants under different organic fertilizer treatments between 15 and 70 days after transplanting Significant increases $(\mathrm{P}<0.05)$ in the wheat plant height, leaf area, number of tillers, stem girth, number of spikelets/plant and leaf population under different organic fertilizers compared to the control treatment (Table $4 \mathrm{a} \& \mathrm{~b}$ ). The highest values of wheat plant height, leaf area, number of tillers, stem girth; number of panicles per plant and leaf population were obtained with the application of poultry manure followed by NPK 15-15-15 fertilizer, pig, goat manures and wood ash respectively. When compared with NPK 1515-15 fertilizer, poultry manure increased wheat plant height, leaf area, number of tillers per plant, stem girth and number of panicles per plant by $14 \%, 10 \%, 2 \%, 11 \%, 15 \%$ respectively except leaf population where NPK 15-15-15 fertilizer increased the parameter by $3 \%$ more than poultry manure. Pig manure also increased the plant height, leaf area, and number of tillers, stem girth, number of panicles and leaf population by 1\%, 14\%, 33\%, 3\%, $8 \%$ and $23 \%$ respectively compared to the goat manure. The wood ash treatment application increased moderately the values of wheat growth parameters while the control treatment where there was no fertilizer application had the least values of growth parameters.

\section{Table 4a.}

\begin{tabular}{|c|c|c|c|c|c|c|c|c|c|c|c|c|}
\hline \multirow{3}{*}{$\begin{array}{c}\text { Treatments } \\
\text { Control }\end{array}$} & \multicolumn{3}{|c|}{ Plant height (cm) } & \multicolumn{3}{|c|}{ Leaf area $\left(\mathrm{cm}^{2}\right)$} & \multicolumn{3}{|c|}{ Number of tillers per plant } & \multicolumn{3}{|c|}{ Stem girth } \\
\hline & \multirow{2}{*}{$\begin{array}{l}2014 \\
21.0 \mathrm{a} \\
\end{array}$} & \multirow{2}{*}{$\begin{array}{c}2015 \\
20.80 a \\
\end{array}$} & \multirow{2}{*}{$\begin{array}{l}\text { Mean } \\
20.90 \mathrm{a}\end{array}$} & \multirow{2}{*}{$\begin{array}{c}2014 \\
11.62 a\end{array}$} & \multirow{2}{*}{$\begin{array}{c}2015 \\
11.20 \mathrm{a}\end{array}$} & \multirow{2}{*}{$\begin{array}{l}\text { Mean } \\
11.41 \mathrm{a} \\
\end{array}$} & \multirow{2}{*}{$\begin{array}{c}2014 \\
4.0 \mathrm{a} \\
\end{array}$} & \multirow{2}{*}{$\begin{array}{c}2015 \\
6.0 \mathrm{a} \\
\end{array}$} & \multirow{2}{*}{\begin{tabular}{|c|} 
Mean \\
$5.0 \mathrm{a}$ \\
\end{tabular}} & \multirow{2}{*}{$\begin{array}{l}2014 \\
0.92 a \\
\end{array}$} & \multicolumn{2}{|c|}{2015 Mean } \\
\hline & & & & & & & & & & & $0.96 a$ & $0.94 \mathrm{a}$ \\
\hline $\begin{array}{c}\text { NPK 15-15- } \\
15\end{array}$ & $76.80 \mathrm{e}$ & $77.40 \mathrm{e}$ & $71.10 \mathrm{~d}$ & $45.10 \mathrm{~d}$ & $42.30 \mathrm{~d}$ & $43.70 \mathrm{~d}$ & $23.40 \mathrm{~d}$ & $22.0 \mathrm{e}$ & $22.70 \mathrm{e}$ & $3.60 \mathrm{f}$ & $2.80 \mathrm{bc}$ & $3.20 \mathrm{c}$ \\
\hline $\begin{array}{l}\text { Poultry } \\
\text { manure }\end{array}$ & $84.70 \mathrm{f}$ & $87.50 \mathrm{f}$ & $85.80 \mathrm{f}$ & $47.40 \mathrm{~d}$ & $49.20 \mathrm{f}$ & $48.30 \mathrm{f}$ & $24.0 \mathrm{~d}$ & $22.0 \mathrm{e}$ & $23.00 \mathrm{ef}$ & $3.40 \mathrm{~d}$ & $3.80 \mathrm{f}$ & $3.60 \mathrm{f}$ \\
\hline Pig manure & $73.80 \mathrm{~d}$ & $75.60 d$ & 11.70 & $47.40 \mathrm{~d}$ & $56.80 \mathrm{e}$ & $47.10 \mathrm{e}$ & $21.70 \mathrm{c}$ & $20.30 \mathrm{~d}$ & $21.00 \mathrm{~d}$ & $3.20 \mathrm{c}$ & $3.60 \mathrm{e}$ & $3.40 \mathrm{e}$ \\
\hline $\begin{array}{c}\text { Goat } \\
\text { manure }\end{array}$ & $65.20 c$ & $66.80 \mathrm{c}$ & $66.00 \mathrm{c}$ & $41.40 \mathrm{c}$ & $39.40 \mathrm{c}$ & $40.40 \mathrm{c}$ & $13.90 \mathrm{~b}$ & $14.10 \mathrm{c}$ & $14.00 \mathrm{c}$ & $3.5 \mathrm{e}$ & $3.10 \mathrm{~d}$ & $3.30 \mathrm{~cd}$ \\
\hline Wood ash & $57.0 \mathrm{~b}$ & $60.80 \mathrm{~b}$ & $59.80 \mathrm{~b}$ & $39.40 \mathrm{~b}$ & $37.60 \mathrm{~b}$ & $38.50 \mathrm{~b}$ & $13.38 \mathrm{~b}$ & $12.50 \mathrm{~b}$ & $12.94 \mathrm{~b}$ & $3.10 \mathrm{~b}$ & $2.70 \mathrm{~b}$ & $2.90 \mathrm{~b}$ \\
\hline
\end{tabular}

Treatment means within each column followed by the same letters are not significantly different from each other using Duncan Multiple Range Test at 5\% level.

Table 4b: The growth parameters of Wheat under different organic fertilizer treatments.

\begin{tabular}{|c|c|c|c|c|c|c|}
\hline Treatments & \multicolumn{3}{|c|}{ Number of spikelets } & \multicolumn{2}{c|}{ Leaf population } \\
\hline & $\mathbf{2 0 1 4}$ & \multicolumn{2}{|c|}{$\mathbf{2 0 1 5}$ Mean } & $10.70 \mathrm{a}$ & $9.30 \mathrm{a}$ & $10.00 \mathrm{a}$ \\
\hline Control & $5.20 \mathrm{a}$ & $4.80 \mathrm{a}$ & $5.00 \mathrm{a}$ & $68.30 \mathrm{f}$ & $65.10 \mathrm{e}$ & $66.70 \mathrm{f}$ \\
\hline NPK 15-15-15 & $14.18 \mathrm{e}$ & $16.50 \mathrm{~d}$ & $15.34 \mathrm{e}$ & $63.50 \mathrm{e}$ & $65.70 \mathrm{e}$ & $64.60 \mathrm{e}$ \\
\hline Poultry manure & $18.40 \mathrm{f}$ & $17.60 \mathrm{e}$ & $18.00 \mathrm{f}$ & $57.70 \mathrm{~d}$ & $53.90 \mathrm{~d}$ & $55.80 \mathrm{~d}$ \\
\hline Pig manure & $11.30 \mathrm{bc}$ & $12.18 \mathrm{c}$ & $11.74 \mathrm{c}$ & $42.40 \mathrm{c}$ & $43.00 \mathrm{c}$ & $42.70 \mathrm{c}$ \\
\hline Goat manure & $12.79 \mathrm{~d}$ & $12.81 \mathrm{c}$ & $12.80 \mathrm{~d}$ & $37.40 \mathrm{~b}$ & $38.80 \mathrm{~b}$ & $33.10 \mathrm{~b}$ \\
\hline Wood ash & $10.50 \mathrm{~b}$ & $11.16 \mathrm{~b}$ & $10.83 \mathrm{~b}$ & & \multicolumn{2}{c|}{ Mean } \\
\hline
\end{tabular}

Treatment means within each column followed by the same letters are not significantly different from each other using Duncan Multiple Range Test at 5\% level.

\section{Effect of different organic fertilizers on the yield param- eters of wheat}

There were significant $(\mathrm{P}<0.05)$ increases in the wheat grains yield $(\mathrm{kg} / \mathrm{ha})$, straw weight and root biomass under different organic fertilizer treatments compared to the control treatments (Table 5). The highest values of wheat grain yields, straw weight and root biomass $(\mathrm{kg} / \mathrm{ha})$ were recorded with the application of poultry manure followed by NPK 15-15-15 fertilizer, pig, goat 
manures and wood ash respectively. Application of poultry manure increased the wheat grain yield, straw weight and root biomass by $13 \%, 2 \%$ and $1 \%$ compared to NPK 15-15-15 fertilizer. In-addition, it was observed that the wheat straw yield and root biomass values in NPK 15-15-15 fertilizer were slightly higher than the pig goat, manures and wood ash respectively. Pig manure increased wheat grain yields, straw weight and root biomass by $16 \%, 2 \%$ and $12 \%$ compared to wood ash. The goat manure and wood ash increased moderately the yield parameters of wheat while the control treatment where there was no fertilizer application had the least values of wheat yield parameters. The higher straw yield and root biomass of wheat in all the treatments also gave an indication of their potential uses as fodder, hay and silage for animals in the study area.

Table 5: The yield parameters of Wheat under different organic fertilizer treatments.

\begin{tabular}{|c|c|c|c|c|c|c|c|c|c|}
\hline Treatments & \multicolumn{2}{|c|}{ Wheat straw weight (kg/ha) } & \multicolumn{2}{c|}{ Wheat root biomass (kg/ha) } & \multicolumn{3}{c|}{ Wheat grains yield (kg/ha) } \\
\hline & $\mathbf{2 0 1 4}$ & $\mathbf{2 0 1 5}$ & Mean & $\mathbf{2 0 1 4}$ & $\mathbf{2 0 1 5}$ & Mean & $\mathbf{2 0 1 4}$ & $\mathbf{2 0 1 5}$ & Mean \\
\hline Control & $1276.00 \mathrm{a}$ & $1256.00 \mathrm{a}$ & $1266.00 \mathrm{a}$ & $336.70 \mathrm{a}$ & $332.30 \mathrm{a}$ & $334.50 \mathrm{a}$ & $752.00 \mathrm{a}$ & $712.00 \mathrm{a}$ & $732.0 \mathrm{a}$ \\
\hline $\begin{array}{c}\text { NPK 15-15- } \\
15\end{array}$ & $3356.30 \mathrm{e}$ & $3542.60 \mathrm{e}$ & $3449.45 \mathrm{e}$ & $1669.20 \mathrm{f}$ & $1629.0 \mathrm{~d}$ & $1649.10 \mathrm{~d}$ & $2120 \mathrm{~d}$ & $2176 \mathrm{c}$ & $2148.0 \mathrm{c}$ \\
\hline $\begin{array}{c}\text { Poultry } \\
\text { manure }\end{array}$ & $3664.10 \mathrm{f}$ & $3464.80 \mathrm{f}$ & $3564.45 \mathrm{f}$ & $1639.20 \mathrm{e}$ & $1702.2 \mathrm{f}$ & $1670.70 \mathrm{f}$ & $2518 \mathrm{f}$ & $2432 \mathrm{e}$ & $2475.0 \mathrm{f}$ \\
\hline Pig manure & $3258.10 \mathrm{c}$ & $3460.10 \mathrm{~d}$ & $3359.10 \mathrm{~d}$ & $1596.0 \mathrm{~d}$ & $1672.20 \mathrm{e}$ & $1634.10 \mathrm{~d}$ & $2400 \mathrm{e}$ & $2430 \mathrm{e}$ & $2415.0 \mathrm{f}$ \\
\hline Goat manure & $3147 \mathrm{~b}$ & $3421.20 \mathrm{c}$ & $3284.10 \mathrm{c}$ & $1553.10 \mathrm{c}$ & $1529.40 \mathrm{c}$ & $1541.25 \mathrm{c}$ & $2210.1 \mathrm{c}$ & $2256.30 \mathrm{~d}$ & $2233.2 \mathrm{~d}$ \\
\hline Wood ash & $3380.10 \mathrm{~b}$ & $3179.10 \mathrm{~b}$ & $3279.60 \mathrm{~b}$ & $1468.0 \mathrm{~b}$ & $1395.0 \mathrm{~b}$ & $1431.50 \mathrm{~b}$ & $2067 \mathrm{~b}$ & $1995.0 \mathrm{~b}$ & $2031.0 \mathrm{~b}$ \\
\hline
\end{tabular}

Treatment means within each column followed by the same letters are not significantly different from each other using Duncan Multiple Range Test at 5\% level.

Proximate analysis of wheat grain yield under different organic fertilizer treatments

The $\%$ crude fibre, $\% \mathrm{~N}, \%$ crude protein and $\%$ crude ash of wheat grains increased significantly $(\mathrm{P}<0.05)$ under different organic fertilizer treatment compared to the control treatment (Table 6). The poultry manure application produced the highest values of wheat grains crude fibre, $\% \mathrm{~N}, \%$ crude protein and crude ash followed by pig, goat manures, wood ash and NPK 15-15-15 fertilizers. Poultry manure treatment increased the wheat grains \% crude fibre, $\% \mathrm{~N}, \%$ crude fibre and crude ash by $27 \%, 33 \%, 33 \%$ and $27 \%$ respectively compared to NPK 15-15-15 fertilizer. Among the organic fertilizer treatments, poultry manure had the highest values of $\%$ crude fibre, $\% \mathrm{~N}$, crude protein and crude ash compared to pig, goat manures and wood ash. Pig manure increased the $\%$ crude fibre, $\% \mathrm{~N}, \%$ crude protein and crude ash by $16 \%, 17 \%, 17 \%$ and $11 \%$ compared to wood ash while the control treatment with no fertilizer application had the least values of wheat grains $\% \mathrm{~N}$, crude protein, crude ash and fibre.

Table 6: Proximate analysis of wheat grain yield under different organic fertilizer treatments.

\begin{tabular}{|c|c|c|c|c|c|c|c|c|c|c|c|c|}
\hline Treatments & \multicolumn{3}{|c|}{ Crude fibre \% } & \multicolumn{3}{c|}{ Nitrogen \% } & \multicolumn{3}{c|}{ Crude ash \% } & \multicolumn{3}{c|}{ Crude protein \% } \\
\hline & $\mathbf{2 0 1 4}$ & $\mathbf{2 0 1 5}$ & Mean & $\mathbf{2 0 1 4}$ & $\mathbf{2 0 1 5}$ & Mean & $\mathbf{2 0 1 4}$ & $\mathbf{2 0 1 5}$ & Mean & $\mathbf{2 0 1 4}$ & $\mathbf{2 0 1 5}$ & Mean \\
\hline Control & $0.93 \mathrm{a}$ & $1.13 \mathrm{a}$ & $1.03 \mathrm{a}$ & $0.48 \mathrm{a}$ & $0.52 \mathrm{a}$ & $0.50 \mathrm{a}$ & $1.23 \mathrm{a}$ & $1.05 \mathrm{a}$ & $1.14 \mathrm{a}$ & $3.08 \mathrm{a}$ & $3.18 \mathrm{a}$ & $3.13 \mathrm{a}$ \\
\hline $\begin{array}{c}\text { NPK 15-15- } \\
15\end{array}$ & $2.40 \mathrm{~b}$ & $2.92 \mathrm{c}$ & $2.66 \mathrm{~b}$ & $0.93 \mathrm{~b}$ & $0.87 \mathrm{~b}$ & $0.90 \mathrm{~b}$ & $1.92 \mathrm{~b}$ & $2.04 \mathrm{~b}$ & $1.98 \mathrm{~b}$ & $5.85 \mathrm{~b}$ & $5.40 \mathrm{~b}$ & $5.625 \mathrm{~b}$ \\
\hline $\begin{array}{c}\text { Poultry } \\
\text { manure }\end{array}$ & $3.56 \mathrm{f}$ & $3.68 \mathrm{de}$ & $3.62 \mathrm{f}$ & $1.30 \mathrm{de}$ & $1.38 \mathrm{f}$ & $1.34 \mathrm{f}$ & $2.75 \mathrm{f}$ & $2.69 \mathrm{e}$ & $2.72 \mathrm{f}$ & $8.10 \mathrm{f}$ & $8.65 \mathrm{f}$ & $8.375 \mathrm{f}$ \\
\hline Pig manure & $3.45 \mathrm{e}$ & $3.63 \mathrm{~d}$ & $3.54 \mathrm{e}$ & $1.24 \mathrm{~d}$ & $1.32 \mathrm{de}$ & $1.28 \mathrm{e}$ & $2.65 \mathrm{e}$ & $2.45 \mathrm{~d}$ & $2.55 \mathrm{e}$ & $7.20 \mathrm{c}$ & $8.20 \mathrm{e}$ & $8.0 \mathrm{e}$ \\
\hline Goat manure & $3.22 \mathrm{~cd}$ & $2.98 \mathrm{c}$ & $3.10 \mathrm{~d}$ & $1.10 \mathrm{c}$ & $1.30 \mathrm{~d}$ & $1.20 \mathrm{~d}$ & $2.30 \mathrm{~d}$ & $2.10 \mathrm{~b}$ & $2.20 \mathrm{c}$ & $7.3 \mathrm{~cd}$ & $7.70 \mathrm{~d}$ & $7.50 \mathrm{~d}$ \\
\hline Wood ash & $3.17 \mathrm{c}$ & $7.75 \mathrm{~b}$ & $2.96 \mathrm{c}$ & $1.0 \mathrm{bc}$ & $1.22 \mathrm{c}$ & $1.06 \mathrm{c}$ & $2.14 \mathrm{c}$ & $238 \mathrm{c}$ & $2.26 \mathrm{~cd}$ & $6.80 \mathrm{e}$ & $6.46 \mathrm{c}$ & $6.63 \mathrm{c}$ \\
\hline
\end{tabular}

Treatment means within each column followed by the same letters are not significantly different from each other using Duncan Multiple Range Test at $5 \%$ level of significance.

\section{Post-cropping soil chemical composition under different organic fertilizers after harvesting wheat.}

The soil pH, O.M, N, P, K, Ca and Mg increased significantly $(\mathrm{P}<0.05)$ under different organic fertilizer treatments compared to the control treatment (Table 7a \& 7b). Application of poultry manure increased soil N, Ca, Mg, pH and \% O.M by 5\%, 98\%, 95\%, $24 \%$ and $90 \%$ respectively compared to the NPK $15-15-15$ fertilizer.
However, NPK 15-15-15 fertilizers increased slightly the soil P and $\mathrm{K}$ by $2 \%$ and $9 \%$ respectively compared to the poultry manure. The NPK 15-15-15 fertilizer also decreased soil pH and O.M. Among the organic fertilizers, poultry manure treatment produced the highest values of soil N, P, and O.M closely followed by pig, goat manures and wood ash treatments. In-addition, wood ash also had the highest values of the soil $\mathrm{K}, \mathrm{Ca}$, $\mathrm{Mg}$ and $\mathrm{pH}$ compared to others. 
Table 7a.

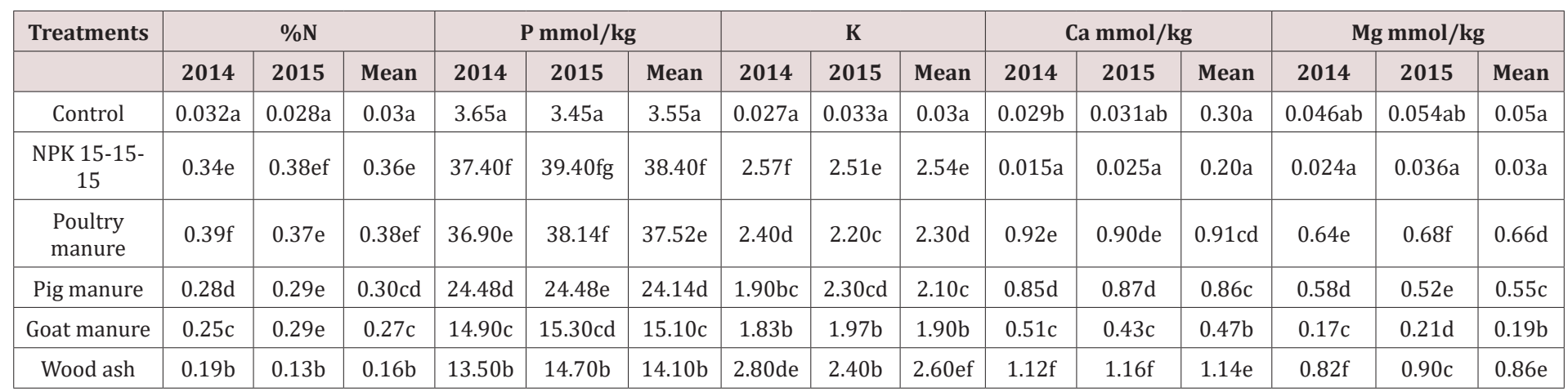

Treatment means within each column followed by the same letters are not significantly different from each other using Duncan Multiple Range Test at $5 \%$ level.

Table 7b: Soil Chemical Composition after harvesting wheat under different organic fertilizers.

\begin{tabular}{|c|c|c|c|c|c|c|}
\hline Treatments & 2014 & Soil pH 2015 & Mean & 2014 & Soil O.M \% 2015 & Mean \\
\hline Control & $5.20 \mathrm{ab}$ & $5.0 \mathrm{a}$ & $5.10 \mathrm{a}$ & $0.22 \mathrm{a}$ & $0.26 \mathrm{ab}$ & $0.24 \mathrm{ab}$ \\
\hline NPK 15-15-15 & $5.14 a$ & $4.90 \mathrm{a}$ & $5.02 \mathrm{a}$ & $0.23 a$ & $0.21 \mathrm{a}$ & $0.22 \mathrm{a}$ \\
\hline Poultry manure & $6.95 \mathrm{e}$ & $6.80 \mathrm{~d}$ & $6.89 \mathrm{~d}$ & $2.40 \mathrm{e}$ & $0.20 \mathrm{e}$ & $2.30 \mathrm{f}$ \\
\hline Pig manure & $6.73 \mathrm{~d}$ & $6.65 c$ & $6.69 c$ & $1.99 \mathrm{~d}$ & $2.21 \mathrm{e}$ & $2.10 \mathrm{e}$ \\
\hline Goat manure & $6.10 c$ & $6.18 \mathrm{~b}$ & $6.14 \mathrm{~b}$ & $1.85 \mathrm{c}$ & $1.89 \mathrm{~d}$ & $1.87 \mathrm{~d}$ \\
\hline Wood ash & $7.10 \mathrm{f}$ & $7.30 \mathrm{e}$ & $7.20 \mathrm{e}$ & $1.28 \mathrm{~b}$ & $1.24 \mathrm{c}$ & $1.26 \mathrm{c}$ \\
\hline
\end{tabular}

Treatment means within each column followed by the same letters are not significantly different from each other using Duncan Multiple Range Test at 5\% level.

Poultry manure treatment increased the soil N, P and O.M by $30 \%, 60 \%$ abd $20 \%$ compared with goat manure while wood ash treatment increased the soil $\mathrm{K}, \mathrm{Ca}, \mathrm{Mg}$ and $\mathrm{pH}$ by $11 \%, 20 \%, 23 \%$ and $4 \%$ respectively compared to the poultry manure treatment. The values of soil $\mathrm{K} / \mathrm{Ca}, \mathrm{K} / \mathrm{Mg}$ and $\mathrm{P} / \mathrm{Mg}$ ratios in NPK 15-15-15 fertilizer treatment were 127:1, 85:1 and 1280:1 respectively compared to $\mathrm{K} / \mathrm{Ca}$ (3:1), $\mathrm{K} / \mathrm{Mg}$ (4:1) and $\mathrm{P} / \mathrm{Mg}$ (57:1) ratios in poultry manure treatment. The control treatment where there was no fertilizer application had the least values of soil N, P, K, Ca, Mg, Soil O.M and $\mathrm{pH}$.

\section{Discussion}

The control treatment had the least values of growth, yield parameters, proximate analysis of wheat and soil properties after harvest and this was due to low soil nutrient status before planting, hence, there is need to incorporate fertilizers to the soil to improve the performance of these growth, yield and soil parameters in wheat. This was in line with Moyin [28] who reported that organic fertilizers applied at 6t/ha increased the soil and leaf, N, P, K, Ca and $\mathrm{Mg}$ concentrations which resulted into an increase in soil $\mathrm{pH}$, O.M content and growth parameters of Coconut seedlings. Similarly, Maqsood [29] reported that the cereal grains and stover yields increased by $37 \%$ and $49 \%$ respectively when fertilizers were incorporated compared to when there was no fertilizer application. The significant increases in wheat plant height, number of tillers per plant, number of spikelets/plant, leaf area stem girth, straw yield, root biomass and grain yields obtained with the application of poultry manure compared to others might be due to its rich and balanced nutrients (N,P,K,Ca,Mg ) and least $\mathrm{C} / \mathrm{N}$ ratio which were made available to wheat crop very quickly for uptake and sustainable performance. This result agreed with the findings of Jubril who reported that higher number of wheat tillers obtained with $7.5 \mathrm{t}$ /ha of poultry manure might be attributed to the more readily available nitrogen which played a vital role in cell division. In-addition, Abdul [11] also reported that wheat has high requirement for nitrogen $(\mathrm{N})$, potassium $(\mathrm{k})$, phosphorus $(\mathrm{P})$, Zinc and sulphur. The deficiency of nitrogen either organic or inorganic forms to wheat will lead to stunted growth and low yield.

Parveen [30] also reported that nitrogen significantly affected the plant height, fertile tillers, number of spikelets, 1000 grain weight and grain yields of wheat. This was because nitrogen played an important role in plant metabolism which increased better seed development, seed maturity and grain production in wheat. The average grain yield of wheat obtained with the application of poultry and pig manures in this experiment compared favorably with the world average of 3010 Kgha-1 and China (4710kgha1) as reported by Abdul [11]. It is believed that planting of new high yielding wheat varieties adapted to the new environment will increase the average yield per hectare in the study area. Phosphorus is important as component of Ribulose 1,5 phosphate and phospho-glyceric acids in photosynthesis (ATP). Therefore, 
wheat is a C3 plant which makes use of sunlight to photosynthesize and produce phosphorus based product that subsequently led to higher grain yields. This observation was supported by Getachew [31]. who reported significant responses of wheat to phosphorus on nitosols in the Central Ethopian highlands. Besides, the prevailing temperature, rainfall amount and insolation hours (sunshine hours) in the study area (Table 1) might also be responsible for the good photosynthetic process and the yields of wheat even without irrigation as practiced in Northern Nigeria and other countries with low rainfall. Hence sustainable increases in wheat yields, depend on adequate level of water and nutrients.

The ratio of straw yield and root biomass to the grain yields of wheat in this experiment was very comparable to the ratio 2:1 obtained by Wang [32]. The straw yields and root biomass are potential sources of fodder and hays for the small and large ruminant animals (goats, sheep and cattle) as part of wheat value chain which is yet to be explored. Besides, the availability of these fodder and hays from wheat will reduce drastically the frequent conflicts between the farmers and normadic herdsmen in the study area and other regions of the world. The root biomass will enhance stability of the soils against erosion which can deplete soil nutrients; also, it will help to stabilize the wheat plants against lodging. This observation was supported by Fischer and Stapper [33] who reported that the use of organic manures reduces soil bulk density which promoted vigorous rooting in wheat and confers stability to the crops against wind attack and reduced lodging. Lodging in cereals also leads to significant reduction in the stover and grain yields. It was also observed that the high nitrogen content in NPK 15-15-15 fertilizer might be responsible for the excessive vegetative growth in wheat plants (i.e luxury consumption) which delayed maturity and subsequently the reduced yields of wheat compared to poultry manure. Besides, the application of NPK 15$15-15$ fertilizer at $300 \mathrm{~kg} /$ ha led to nutrient imbalance as shown in the high soil $\mathrm{K} / \mathrm{Ca}, \mathrm{K} / \mathrm{Mg}$ and $\mathrm{P} / \mathrm{Mg}$ ratios which made nutrient availability difficult and the uptake of $\mathrm{P}, \mathrm{K}, \mathrm{Ca}$, and $\mathrm{Mg}$. This could also be responsible for the lower wheat grains yield, tillers, number of spikelets, root biomass and so forth. The above observation agreed with Moyin [34] who reported that continuous use of NPK 15-15-15 fertilizers and other chemical fertilizers promoted decline in soil organic matter, decrease uptake of $\mathrm{K}, \mathrm{Ca}$ and $\mathrm{Mg}$ as well as increasing soil acidity. Increase acidity (low $\mathrm{pH}$ ) significantly affected soil microbes activities (pseudosomonas, nitrosomonas and nitrobactor) which played active part in nitrogen cycle supply of nitrogen to the soils for crop use as reported by Odu [35].

Moyin [25] also reported that interactions of soil $\mathrm{K} / \mathrm{Ca}, \mathrm{K} / \mathrm{Mg}$ and $\mathrm{P} / \mathrm{Mg}$ in NPK fertilized soils will lead to nutrient dilution and could be responsible for the lower quality indices of wheat grain yield (crude fibre, crude ash, nitrogen and crude protein). Besides, Maqsood [29] reported excessive uptake of nitrogen would lead to luxury consumption and prolonged maturity leading to Nitrogen -phosphorus interaction in NPK 15-15-15 fertilizer application.
The ultimate end is nutrient dilution and low yields of wheat. Nevertheless, this type N/P interaction was not noticed in the experiment conducted by Parven [30] using organic manures. The NPK fertilizers contained mainly N, P and K and very low traces of $\mathrm{Ca}$ and Mg. Tong [36] reported that excess nitrogen in chemical fertilizers might be leached downwards to pollute underground water. Calcium (Ca) has been reported to increase the root biomass which subsequently increased the nutrient uptake by wheat plants for high grain yields while $\mathrm{Mg}$ is also important in the formation of chlorophyll with nitrogen. This will encourage higher photosynthesis rate culminating into formation of high number of wheat tillers number of spikelets and grain yield as noticed in the poultry, pig, goat manures and wood ash fertilized plots in the experiment. The above observation was supported by Craighead and Martin [37] who reported that there was a significant increase in wheat grain yield, tillers and spikelets to Magnesium (Mg) fertilizer application.

Wood ash application to soils increased most the soil $\mathrm{pH}$ and this could be due to its having the highest values of $\mathrm{K}, \mathrm{Ca}$ and $\mathrm{Mg}$ (exchangeable bases) which subsequently increased the soil buffering capacity and base saturation as observed by Moyin [29]. Besides, Obatolu [38] also reported that soil pH influenced nutrient availability and uptake of nutrients by crops. Potassium is important in wheat grains filling and formation, strengthening of plant stems, opening and closing of stomata and cell division for higher photosynthetic rate. This could be responsible for the better grain yield, number of tillers and spikelets of wheat in wood ash fertilizer treatment. This observation was also supported by Adu Daap [39] who reported that cocoa pod ash and wood ash increased the availability and uptake of soil $\mathrm{K}$, Ca and Mg nutrients in soils. Owureke [40] reported that potassium is important in water conservation, enhancing flowering, fruit maturity and yield of crops particularly in pineapple. However, the highest $\mathrm{C} / \mathrm{N}$ ratio of wood as compared to that of poultry and pig manures could hamper decomposition and reduced the release and uptake of nutrients. This could be responsible for the lower wheat grain yield, root biomass and growth parameters in wood ash fertilized plots. The processing of the organic fertilizers in this study helped to reduce their $\mathrm{C} / \mathrm{N}$ ratios and the results obtained would have been extremely different if unprocessed organic fertilizers were used. Adebayo [41] reported that the $\mathrm{C} / \mathrm{N}$ ratio of unprocessed saw dust and wood ash were 135:1 and 130:1 respectively, hence, the need for processing of organic fertilizers to reduce $\mathrm{C} / \mathrm{N}$ ratio. The tillage practices such as ploughing and harrowing employed in this research were also important in the establishment of transplanted wheat seedlings in the field. The soils tilth was improved which made the seedlings to root easily and this reflected in the increased number of tillers, spikelets and grain yield of wheat as observed by Moyin [42] who reported that tillage practices significantly improved the establishment and yield of cabbage. Besides, the application of organic fertilizers such as wood ash, pig, goat and 
poultry manures reduced the soil bulk density and increased soil porosity as observed by Moyin [43] who reported that wood ash and the amended forms with poultry reduced significantly the soil bulk density and subsequently improved root development.

One of the major significant contributions of this study was the raising of wheat seedlings in the shaded nursery for full establishment in the field after transplanting. Direct sowing of wheat seeds in the field did not have good germination because of direct impact of weather (temperature and water stress). This observation was in line with the work of John [44] who reported that high temperature $>35.4 \mathrm{C}$ and water stress were inimical to the growth of wheat at leaf initiation stage, shoot growth, vernalisation, terminal spikelets, anthesis and grain filling. The crude ash, nitrogen, protein and crude fiber contents of wheat grains in this study were very comparable and adequate when compared with $1.17-2.96 \%$ crude ash, $8.3-19.3 \%$ protein and $1: 11-2 \%$ crude fiber obtained by Davis [45] indicating that the application of poultry manure, pig, goat and wood ash fertilizers increased the quality indices of wheat. Therefore, the significant improvement in crude fiber, ash and protein of wheat could be linked to the nutrient compositions of pig, poultry, goat and wood ash which translated to ensuring high quality indices. This observation was supported by Zuzana [46] and Davis [47] who reported that grains quality content such as carbohydrate, protein, minerals, crude fibre and ash were derived from crops when consumed by people. The intake of these nutrients would enhance sound health and productivity which would reduce the amount of money expended in buying synthetic drugs and supplements. Crude ash and crude fiber are reported to have beneficial effects in protection against heart disease, cancer, normalization of blood lipids, regulation of glucose absorption and prevention of constipation while protein is responsible for the body development and growth Flagella [48]. In-addition, another significance of this research work is that the successful domestication of wheat in South West Nigeria has opened wide opportunities in wheat value chains by providing raw materials for establishment of more confectioneries enterprises (baking breads, biscuits, cakes, cookies, pasta and noddles) which will bring more income for farmers and reduced the increasing rate of unemployment programmes.

This success could be replicated in all the Southern areas of West Africa (Benin, Togo, Ghana, Cote d'voure, Gambia, Liberia, Sierra Leone, Senegal and Gambia) and other regions in the world with similar climatic conditions. Furthermore, the domestication of wheat in South West Nigeria under rainfed agriculture in the second cropping season (July-Nov) has reduced significantly the cost of irrigation as being practiced in the Northern region of Nigeria, drier parts of Asian countries (Iran, Iraq, Syria etc) and African countries. The increasing effects of climate change in reducing the volume of irrigated water in dams coupled with extreme high temperature and low rainfall amount in the Northern parts of Nigeria and other drier regions in the world for wheat cultivation had created a serious threat to wheat production in the world, thus, increasing the wide gap of supply and demand for the crop. Flagella [49] reported that water stress adversely affected plant establishment, growth and cell development. It also diminishes photosynthesis and affect grain yield at milking and filling stage in wheat. However, it is suggested that further research studies should be carried out to develop more high yielding varieties of wheat that are adaptable to the climatic fluctuations, drought, pest and diseases resistance in Nigeria and other countries in the world willing to domesticate wheat cultivation on commercial basis.

\section{Recommendation and Conclusion}

The research work has shown vividly that the use of different forms of organic fertilizers namely pig, poultry, goat manures and wood ash applied at 6t/ha significantly increased the wheat growth, grain yield parameters, crude fibre, crude ash, protein, nitrogen qualities, soil $\mathrm{pH}$, organic matter, N.P,K, Ca and Mg. Hence, it is recommended that poultry manure be applied at $6 \mathrm{t} /$ ha to increase availability of essential soil nutrients, growth, grain yield parameters, crude ash, crude fibre, and nitrogen and protein qualities of wheat which would enhance sustainable production of wheat on commercial basis. In-addition, if there is scarcity of poultry manure in your environment, pig manure is also a good alternative to it in term of performance. Besides, the use of poultry manure would substitute for application of high quantity of NPK1515-15 fertilizer. This recommendation is very essential because the purchase of inorganic fertilizers by small scale and commercial farmers of wheat is very expensive/exorbitant. Also, the benefits of secondary/residual effects of these organic fertilizers on soil fertility improvement and enhancing sustainability of the environment must be considered as important.

\section{References}

1. Dubcousky J, Dvorack J (2007) Genome plasticity A key factor in the success of polyploidy wheat under domestication. Sci J 316(5833): 1862-1866.

2. Iftikhar HM, Shanisad HS, Sajjah H, Khalid I (2002) Growth, yield and quality response of three wheat (Triticum aestivum $L$ ) varieties to different levels of N, P and K. Intl J Agric and Bio 3(1): 362-364.

3. Hussain I, Khan MA, Khan E (2006) Bread wheat varieties as influenced by different nitrogen levels. J Zhesia Univ Sci 7(1): 70-80.

4. Shewry PR (2009) Wheat potentials. J Expl Bot 60(6): 1537-1553.

5. Sharma MP, Gupta JP (1998) Effect of organic materials on grain yield and soil properties in maize - wheat cropping systems. Indian J Agric Sci 68(1): 715-717.

6. Shewry PR, Halford NG, Lafiandra D, Hall JC, Dunlop JC, et al. (2003) The genetics of wheat gluten proteins. Advances in genetics 49: 111-184.

7. CBN (2012) Central Bank of Nigeria Annual Report. 1: 20-26.

8. Moyin Jesu EI (2003) Incorporation of agro-industrial biomass and their effects on growth and nutrient content of four successive crops of Amaranthus. Pertarika J Agric Sci 26(1): 49-58.

9. Feldman M, Smart J, Simmonds NW (1995) Wheat, Evolution of plants. Harlow, UK Longman Scientific and Technical Publication. pp. 185-192. 
10. Jubrin AD, Fayam AS (2012) Effect of poultry manure on herbage production of wheat varieties grown in Bauchi, Nigeria. Savannah J Agric $7(2): 10-15$.

11. Abdul Latif M, Asmat UM, Sattar A, Fiaz H, Abbas G, et al. (2010) Response of growth and yield of wheat to NPK fertilizers. Sci Int (Lahore) 24(2): 185-189.

12. Jabbar AT, Aziz IH, Bhatti ZA, Virk MM, Wasl UD (2009) Effect of potassium application on yield and protein contents of late sown wheat (Triticum aestiwum $L$ ) under field conditions. Soil and Environment 28(2): 193-196.

13. Soil Survey Staff (1999) Soil taxonomy. A basic system for soil classification for making and interpreting soil survey Agric. handbook no 436 USA, Washington DC, USA.

14. Murphy J, Riley JP (1962) A modified single solution method for determination of phosphate in natural waters. Anal Chem Acta 27: 3136.

15. Crockford L, Nowel O (1957) Laboratory manual of physical chemistry. John Wiley sons, New York.

16. Walkley A, Black IA (1934) An examination of degtajroff method for determining soil organic Matter acid and a Proposed Modification of the Chromic Acid Titration method. Soil Sci 37: 29-38.

17. Jackson ML (1958) Soil Chemical analysis. NJ Prentice Hall Englewood Cliffs pp. 57-69.

18. Jackson ML (1964) Soil Chemical analysis NG Prentice Hall, Englewood Cliffs. pp. 86-92.

19. Bouycous H (1951) Mechanical analysis of soils using hydrometer method. Analytical Chem. Acta 2: 32-34.

20. Agboola AA, Corey RB (1973) Soil testing N, P, K for maize in the soils derived from metamorphic and igneous rocks of Western State of Nigeria. J West Afr Sci Assoc 17: 93-100.

21. Folorunso 00, Agboola AA, Adeoye GO (2000) Evaluation of three fertilizer models for $\mathrm{P}$ and $\mathrm{K}$ recommendation in maize (Zea mays $L$ ). J Tech Edu 2: 237-253.

22. Adeoye GO (1986) Comparative studies of Ammonium bi-fluoride chelate extractants and some convectional extractants for sedimentary soils of South Western Nigeria. Ph.D Thesis Agronomy Department, University of Ibadan, Ibadan, Nigeria, pp. 50-60.

23. Sobulo RA, Osiname OA (1981) Soils and fertilizer use in Western Nigeria. Tech Bull No 11. Institute of Agricultural Research and Training, Univ of Ife, Nigeria.

24. Folorunso 00 (1999) Use of plant residues for improving soil fertility and yield of Okra (Abelmoshus esculentum L Moench and Amaranthus (Amaranthus Viridis L). Ph.D Thesis School of Agric and Agric Tech, Federal Univ of Tech, Akure, Nigeria, pp. 45-50.

25. Moyin Jesu EI (2008) Determination of soil nutrient levels for maximum yield of okra using sole and amended plan residues. J Trop Agric Sci 31(2): 233-225.

26. AOAC (1970) Official method of analysis ( $12^{\text {th }}$ eds.) Association of Official Analytical Chemists Arlington, VA, USA.

27. Gomez KA, Gomez AA (1984) Statistical procedures for agricultural research, $\left(2^{\text {nd }} e d n\right)$, John Wiley and Sons, New York.

28. Moyin Jesu EI, Ogochukwu AI (2014) Comparative evaluation of different organic fertilizer effects on soil fertility, leaf chemical composition and growth performance of coconut (Cocos nucifera L.) seedlings. Int J Plant Soil Sci 3(6): 737-750.

29. Maqsood M, Abid AM, Igbal A, Hussai MT (2001) Effect of variable rate of nitrogen and phosphorus on growth and yield of maize (golden). Online Jour Biological Sci 1(1): 19-20.
30. Parveen K, Liaquat A, Amber R, Ammarah M, Saman M, Sana R, Nazish I (2015) Effect of different levels of nitrogen on the economic yield of wheat (Triticum aestivum $L$ ) variety Aas -11. Intl J Agronomy \& Agric Research (IJAAR) 6(3): 7-11.

31. Getachew A, Paul N, Micheal IB, Christy VB (2015) phosphorus response and fertilizer recommendation for wheat grown on ritosols in the Central Ethopian Highlands. Comm Soil Sci \& Plant Anal 2(1): 1-30.

32. Wang F, Wang Z, Kou C, Ma Z, Zhao D (2016) Responses of wheat yield, macro and micronutrients and heavy metals in soils and wheat following the application of manure compost on North China plain. pp. 1-20.

33. Fischer RA, Stapper M (1987) Lodging effects on high yielding crops of irrigated semi-dwarf wheat. Field Crops Research 17(3-4): 245-248.

34. Moyin Jesu EI (2015) Use of different organic fertilizer on soil fertility improvement, growth and head yield parameters of Cabbage (Brassica Oleraceae L). Int J Recycl Org Waste Agricult 4(4): 291-298.

35. Odu CT (1977) Contribution of free living bacteria to the nitrogen status of humid tropical soils In: Ayanaba A and Dart W (eds). Conf Proc on roles of biological fixation in soils held at International Institute of Trop Agric, Ibadan, Nigeria, Chichester Wiley and Sons, pp. 257-266.

36. Tong Y, Ove E, Dianguing L, Harald G (1997) Effect of organic manure and chemical fertilizers on nitrogen uptake and nitrate leaching in a Eum orthic anthrosols profile. Nutri Cycl Agroecosyst 48(3): 225-229.

37. Craighead MD, Martins JD (2001) Responses to magnesium fertilizers in wheat in Mid-Canterbury. Agronomy J New Zealand 31(1): 63-67.

38. Obatolu CR (1995) Nutrient balance sheet of Alfisol grown to Coffee and maize using organic fertilizers. In Agboola AA (eds) Proceedings $3^{\text {rd }}$ Annual Conference of All African Soil Sci Society, University of Ibadan, Ibadan, Nigeria, pp. 250-256.

39. Adu Daap HK, Cobbina J, Asare EO (1994) Effect of Cocoa pod ash on the growth of maize. J Agric Sci Cambridge 122(1): 31-33.

40. Owureke Asare M, Agyei Amponsah J, Agbemavor SWK Apetev J, Sarfo AK, Okyere AA, et al. (2015) Effect of organic fertilizers on physical and chemical quality of sugar loaf pineapple (Ananas comosus $L$ ) grown in two ecological sites in Ghana. Afri J Food Agric Nutri \& Dev 15(2): 20-50.

41. Adebayo A, Olayinka A (1984) The effects of methods of application and processing of sawdust on plant growth, nutrient uptake and soil chemical properties. Ife Jour of Agric 2(1): 36-44.

42. Moyin Jesu EI, Odewande A (2013) Comparative evaluation of different tillage practices and method of planting on soil properties, growth and head yield of cabbage. Amer J Res Commun 1: 1-20.

43. Moyin Jesu EI, Ojeniyi SO (2006) Effects of sole and amended plant residues on soil nutrient contents and yield of Okra (Abelmoschus esculentum L). Discov Innov J 18(4): 318-326.

44. John RP, Morgan G (1999) Temperature, the growth and development of Wheat: a review. European J Agronomy 10(1): 23-26.

45. Davis KR, Cain RF, Peters LJ, Tourneau DL, M Ginnis J (1980) Evaluation of the nutrient composition of wheat. II. Proximate analysis, Thiamin, Riboflavin, Niancin and Pyridoxine: Cereal Chemistry 58(2): 116-120.

46. Zuzuna S, Edita G, Ernest S (2009) Chemical composition and nutritional quality of wheat grain. Acta Chimica Slovaca 2(1): 115-138.

47. Flagella Z (2006) Nutritional and technological quality of the durum wheat. Italian Journal of Agronomy 1(1): 203-209.

48. Flagella Z, Giuhani MM, Giuzio L, Volpi C, Masci S (2010) Influence of water deficit on durum wheat storage protein composition and technological quality. European Jour Agron 33(3): 197-207.

49. Pandey SK, Hema S (2011) A simple cost effective method of leaf area estimation. J Botany 11(1): 6. 


\section{(C) (i) This work is licensed under Creative Commons Attribution 4.0 License}

To Submit Your Article Click Here:

Submit Article

DOI: 10.32474/CIACR.2018.02.000139

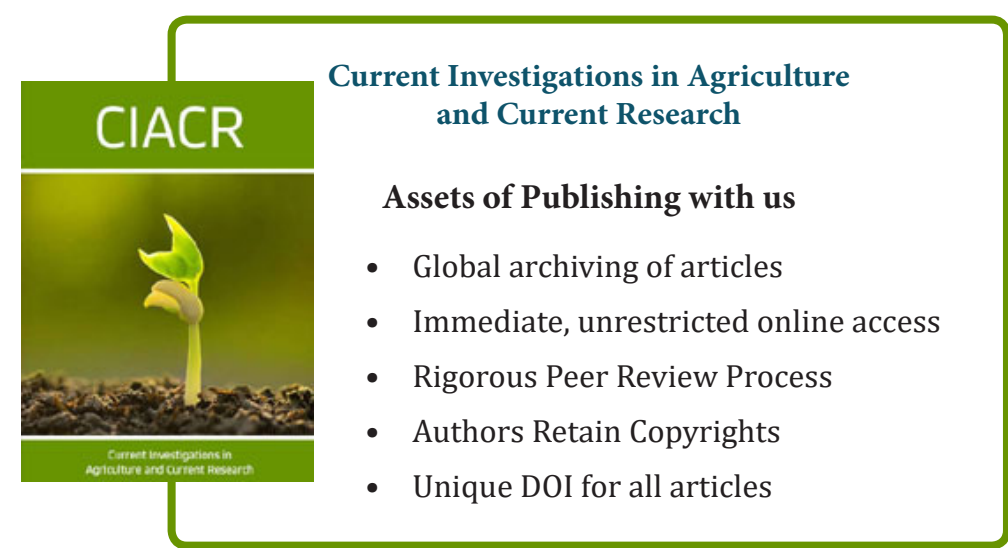

